\title{
Small French Wineries' Export Strategies to China
}

\author{
Dr. Michele Ambaye \\ Dept. of Marketing, Pau Business School \\ Campus Universitaire, 3 Rue St John Perse, Pau Cedex 64074, France \\ Tel: 33-666-993-274Ｅ-mail: michele.ambaye@esc_pau.fr
}

Received: September 3, 2014 Accepted: November 25, 2014 Published: February 1, 2015

doi:10.5296/jmr.v7i2.6936

URL: http://dx.doi.org/10.5296/jmr.v7i2.6936

\begin{abstract}
Over the past 2 decades, wine sales of the leading traditional wine producing countries (France, Italy and Spain) have faced increasing international competition. Sales have been eroded by encroachment from other beverages, changing lifestyles, demography, increased production of other European producers and the economic crisis. Conversely, French wine export has begun to increase with estimates for 2013 at 7,835 million Euros (OIV, 2014; XERFI 700, 2014). This is due to wine consumption increasing in the USA and China, two of the main export markets for France (De La Chesnais, 2013; Julien, 2013).

Business strategies appropriate of large scale wine producers from France, Italy and Spain, have been much studied and written about. In sharp contrast, little has been said about the strategies appropriate to smaller producers facing similar issues (Remaud et al., 2004; Coelho $\&$ Rastoin, 2006). This paper intends to contribute to the paucity of literature about small wine producers' export strategies. It therefore analyses the current situation in the South West of France, taking as example small independent wineries in Jurançon, a little known wine region nestled at the base of the Pyrenees Mountains. This paper therefore examines small wineries' strategies for exporting to China and details an empirical study of independent wine producers in Jurançon and suggests areas for further research.
\end{abstract}

The main findings point to the lack of a clear export strategy for small wine producers such as the Jurançon wine producers. Due to a lack of experience and knowledge of the Chinese market, most small wine producers did not see much potential and until recently were able to sell all of their production to the French market and did not need to investigate export possibilities. However, more recently, through an increasing demand for French AOC wine from the Chinese market, and other foreign markets, they have started to look at ways to produce more to be able to satisfy some of the demand.

As their export intentions are still in their initial stages, there are many complexities that still 


\section{Macrothink}

Journal of Management Research ISSN 1941-899X 2015, Vol. 7, No. 2

need to be researched before a clear strategy can be defined. However, some small Jurançon wineries are actively involved and are far ahead in the process of developing a strategy for export.

Keywords: French Wine, International Strategies, Chinese Market 


\section{Introduction}

Over the past 2 decades, wine sales of leading traditional wine producing countries (France, Italy and Spain) have been increasingly eroded by New World Wines - mainly from Australia, New Zealand, USA, South America and South Africa (Remaud et al., 2004; Campbell \& Guibert, 2006; Alonso \& Northcote, 2009). Decreasing sales have also been due to an increase in sales of other beverages, changing lifestyles, demography and increased wine production of other European producers (Xerfi, 2014).

In the particular case of France, over the period 2005-2008, wine production fell just over 20\% in volume terms (Pouch, 2011; OIV, 2014; XERFI 700, 2014). In 2008, still wine production in France was the lowest in recent years with approximately 33,000,000 hectolitres (XERFI 700, 2014). (This was mainly due to poor weather conditions in 2008). By the end of 2013, production had only slightly increased by $+1.8 \%$ with a predicted $+0.5 \%$ in 2014.

French wine exports hit an all-time low in 2009 at 5,551 million Euros (worldwide sales), however since then they have begun to increase with estimates for 2013 at 7,835 million Euros (OIV, 2014; XERFI 700, 2014). This is due to wine consumption increasing in the USA and China, two of the main export markets for France: 821 million euros in 2013 (China) and 1.049 million euros in 2013 (USA) (XERFI 700, 2014; De La Chesnais, 2013; Julien, 2013).

European wine consumption is still facing the impact of consumers spending less due to the recent economic crisis, and lowering consumption of wine in general (Blot \& Janvier, 2012; XERFI 700, 2014). Despite these facts, French wine remains Europe's top seller (Pouch, 2011; Dever \& Baldi, 2012). Faced with such challenges, certain wine producers in France are working together to counter foreign threats (Remaud et al., 2004) and increasingly beginning to think about export.

Given this backdrop of an ever changing international market landscape, business strategies appropriate to incumbent large scale wine producers from France, Italy and Spain, have been much studied and written about. In sharp contrast, little has been said about the strategies appropriate to smaller producers buffeted by the same harsh winds (Remaud et al., 2004; Coelho \& Rastoin, 2006). Given that a majority of wine producers in Europe are small, the importance of conducting research in this area cannot be underestimated.

This paper explores how smaller $\mathrm{AOC}^{1}$ producers, such as Jurançon (a wine region in South West France) have attempted to cope with existing pressures their attempts to counter the looming and rapid internationalisation of the world wine market and their increasing interest in export.

In the following sections the current state of the generic French wine market and the profile of Jurançon wine, its history, its production and its marketing are described. Legislative impacts of recent changes in EU rules on wine production are briefly described and niche wines such Jurançon are detailed and evaluated. The final section of the paper focuses on export by Jurançon producers. 
${ }^{1}$ AOC $=$ Appellation d'Origine Contrôlée (indicates the geographical origin, quality and (generally) the style of a wine (INAO, 2012).

\section{French Competitive Environment}

The recent economic malaise of the French wine industry has been much studied. The crisis has international, national and regional dimensions that span the short, medium and long term. The causes as well as the impacts have been documented by a number of authors (Remaud et al., 2004; Coelho \& Rastoin, 2006; Duquesnois et al., 2010; Dever \& Baldi, 2012), such as the decrease of wine consumption nationally and internationally which has led to a supply and demand imbalance (Atout France, 2010; Marketline, 2014). Competitive forces in hitherto safe markets at home and abroad, have started to change, due to an increase of wine producing nations (Atout France, 2010; De Battista, 2011; Marketline, 2014).

Moreover, demand for wine in France has been dropping steadily over the past four decades, from 160 litres per head and per year in 1965, to less than 57 litres in 2010 (Bova, 2012). This reflects the changing nature of consumption habits of the French consumer, where wine is increasingly becoming a luxury item or 'quality' product, consumed less frequently, and more for pleasure. Government campaigns on road safety and health (Atout France, 2010) have also contributed to an increased awareness and reduced consumption (Ruhlmann, 2014). However, French consumers still drink more than other countries and France still remains the wine top producer in the world, a position closely shared with Italy and/or Spain, and ahead of the USA and Germany (France Agrimer, 2012).

Many industry commentators also suggest that the intrinsically complicated and regulated domestic market has become too much of a burden for wine producers. AOC regulations coupled with evermore strict EU rules have resulted in double-edged effects of protecting domestic market share, yet hampering creativity and reactivity needed to compete abroad (European Commission, 2009; INAO, 2012).

However, not all French wine producers are facing a bleak future. While much of the French industry continues to struggle with the crisis, a small appellation, known as Jurançon, appears to demonstrate a sustainable and stable commercial position. A number of factors have contributed to this, including a loyal, regional customer base, low levels of export dependency, a good quality wine well-known in the region and an agility and reactivity that is related to its inherently small-scale production.

\section{Jurançon in Context: Wines, Region and History}

The name Jurançon is derived from a small village situated in the South West France, just South of the city of Pau in the Aquitaine Region at the base of the Pyrenees mountains. The vineyards of Jurançon are within the rectangle of Pau-Lasseubetat-Navvarrenx-Lagor and between the Gave (river flowing down from the Pyrenees mountains) through Pau and Oloron.

It is located in an area known as Béarn, which stretches over an area of $20 \mathrm{~km}$ square and comprises 25 communities and around 350,000 inhabitants in 2011 (INSEE, 2010; Pau Porte des Pyrénées, (PPP) Tourisme, 2013). 
The Jurançon label is a protected name used to describe the wine making efforts of an estimated 300 independent wine growers who have an average size vineyard of around 8 hectares (Laprun, 2014; Ruhlmann, 2014). Two white wines are produced, a dry wine known as 'Jurançon Sec', assigned AOC in 1975; and a sweet wine, simply known as 'Jurançon'. The sweet Jurançon, having been first approved AOC in 1936, is thus the 'grande dame' of AOCs in France.

Introduced into the region by the Romans, and having had its first exposure at the baptism of the King Henri IV in 1553, Jurançon wine has become established as a wine of ceremonies in the context of French wines.

\subsection{Jurançon Wine Production}

The annual total production in Jurançon for 2011 was around 54,000 hectolitres, or around 7.2 million bottles (Ruhlmann, 2014) (see Table 1). The sweet Jurançon made up $75 \%$ of this total production (Cave de Gan Jurançon, 2014; INAO, 2012; Laprun, 2014).

There are two groups of producers who are divided according to whether they work independently or as part of a cooperative. In general, once the grapes have been harvested, cooperative and/or independent merchants take over. The latter may purchase the wine in bulk or already bottled prior to marketing it. They may act on behalf of themselves or others to crush, mix, ferment and age the grapes into the desired type of wine.

The independents, known as Route des Vins des Jurançon (RDVJ), include about 130 major independent firms in the core of the industry. Of these, 65 are officially wine producers of AOC Jurançon, 11 are so-called 'négociants' (merchants) and 54 are simply growers (Laprun, 2014). The total production for 2011 for these independent firms was estimated to be 19,270 hectolitres.

The other grouping consists of a cooperative known as the 'Cave de Gan Jurançon' (CDGJ). Their stated aim is to '...work together for their mutual, social, economic, and cultural benefit' (Cave de Gan Jurançon, 2014). Their strategy for this niche wine is focussed on quality and ensuring that it remains a special 'niche' wine. There are currently 270 members, of which 220 provide the cooperative with Jurançon grapes. The cooperative then ferments, bottles and distributes the wine to various customers. The total production in 2011 for the cooperative was estimated to be 29,000 hectolitres (Laprun, 2014).

Table 1. Five year history of production volume for independent wine growers and Cooperative of Jurançon wines (Laprun, 2014).

\begin{tabular}{|l|l|l|l|l|l|}
\hline YEAR & 2007 & 2008 & 2009 & 2010 & 2011 \\
\hline Independent & 17865 & 17185 & 13737 & 20196 & 19270 \\
\hline $\begin{array}{l}\text { Cave de } \\
\text { Jurançon }\end{array}$ & 25862 & 25748 & 21799 & 27626 & 29100 \\
\hline
\end{tabular}

Thus with barely $0.11 \%$ of total French production, Jurançon is simply a drop in the ocean by 
French and international standards. There is no doubt that it is a niche product.

\subsection{Marketing and Sales}

The region sells its products to a network that encompasses direct sales, large retail distributors, cooperatives, as well as a variety of smaller retailers including bars, restaurants, wine specialists and wine exporters.

There appears to be increasing understanding between the two groupings that this multi-channel distribution approach is a tool to enable delivery to consumers of the range of Jurançon wines from premium to standard quality without confusing the end-consumer.

This is important as the retail price of a bottle of AOC Jurançon wine is typically more expensive than the average in France. Prices of dry Jurançon wines vary from $€ 4$ - $€ 10$, while prices of sweet Jurançon vary from $€ 5.20$ - €37.00. Due to the selective distribution strategy of Jurançon wine producers, consumers have less choice of Jurançon wine in supermarkets, where prices range from $€ 4.90$ to $€ 14.90$. Often the latter is not the same wine that is sold in wine specialists or through the 'Domaines' ('Chateaux' - the wine producers' land and cellars).

\subsection{Local and National Market Focus}

Jurançon wine sales have experienced a steady growth over the past decade, except in some years when the economic crisis has had more impact or the harvest has been poor. The economic crisis of 2008, for example, led to a drop in sales, however the effects were not as pronounced for other regions, where red wines or 'run of the mill' white wines were the mainstay of the wine industry (Laprun, 2014; Ruhlmann, 2014; Saubot, 2014).

The sweet Jurançon is a 'niche' wine and most of the consumption is localized within the region known as the 'Grand Sud' (Great South) with a small proportion being sold in other parts of France. The strongest competition is from other wines of the South West such as Madiran red wine (Gers, Haute Pyrénéees, Pyrénées Atlantiques) and from other well-known white wines, such as from the Alsace region, along with some imported wines.

However, the dry Jurançon is less of a niche wine. Competition is more evident for this product, given that dry white wine consists of a third of all wine sales in the whole of France (Vinetsociété.fr, 2014; France Agrimer, 2012). In particular, there is strong competition from wines that come from Pays des Côtes de Gascogne in the Gers - a region bordering the Pyrénées Atlantiques region.

Falls in production as a result of weather conditions have posed more threats for survival than lack of demand. It is generally agreed that each Jurançon bottle produced has a very high likelihood of finding a home (Laprun, 2014 (a); Ruhlmann, 2014; Saubot, 2012).

\section{Export Opportunities}

Conversely, competitive pressures in the home market often encourage the defensive action of exporting (Moen \& Servais, 2002; Campbell \& Guibert, 2006). The upside of Jurançon being dependent on the local or national market, is that it has somewhat been sheltered from 
the occasional turbulence of the international wine market.

Only a small percentage of Jurançon wine (about 10\%) is currently exported. The export approach used by Jurançon producers so far is based on fulfilling ad-hoc demand. Key importers are mostly in the EU including Belgium, Luxembourg, Netherlands and the UK. Sales have also been recorded in countries further away such as the North of Europe, the USA and Canada. At present there appears to be little interest in creating and maintaining an international sales network due to the upfront and long term costs involved.

However, there is a clear realisation amongst small wineries of the Jurançon region that, in the long term, export success could have multiple benefits that will enable Jurançon wine to compete with better known international wines and to cope with contingencies in the home market. Up to now, factors relating to low brand recognition and the cost versus volume quotient have been export barriers. Both make reliance on exportation a difficult decision to justify for such small scale producers.

The funding issue for export is one of the issues addressed by the recent EU regulatory changes. The new rules means that wine producers will be able to request assistance to promote their wines outside the EU. Jurançon producers, like other small producers, will be eligible for assistance of up to $50 \%$ of costs of international marketing intitiatives. This covers funding for market research, public relations, promotion or advertising in non-domestic markets to improve their exposure and competitiveness (Council Regulation (EC), 2009). This is good news for wine producers with limited budgets who want to internationalise their products.

Given its constraints of size and relative lack of renown, the challenge in the next decade for Jurançon wine is whether to mitigate possible increased domestic competition by securing additional sales from export to EU and non EU markets, such as China.

As research has shown (Viot \& Passebois-Ducros, 2010), one of the root causes of the decline of French wines is very much related to positioning confusion. France is famous for its luxury brands and its reputation as a wine-based gourmet culture, with premium prices to match. This image carries well, amongst educated consumers. Surveys have shown that a majority of educated consumers thought country of origin, grape variety and AOC were the most important factors in selecting a wine (Balestrini \& Gamble, 2006). In China this is typically the case where AOC and premium wine brands are in high demand as luxury products (Gaillot, 2014).

\section{Methodology}

As the objective is to gain a better understanding of the underlying motivations of small French wine producers towards export opportunities, the chosen approach was a qualitative one.

An initial stage of research in the form of a literature review pertaining to the current marketing strategies of Jurançon wine (Ambaye, 2013) pointed to a phenomenon of an increasing interest in export, which had never before been contemplated by the small wine 
producers.

To enable a clearer understanding of the situation in more depth and to get a better picture of the strategies being implemented, an empirical approach was implemented. One-to-one interviews were carried out (Flick, 2014; Wisker, 2007) and a guideline questionnaire was used to direct the main themes. Following this an analysis based on a grounded theory analysis method was carried out (Strauss \& Corbin, 1998).

5 key respondents were interviewed: the Export Director for Route des Vins de Jurançon, Mr. Gaillot; a renowned independent, with a large percentage of production of Jurançon wine, Pierre Saubot; the Export Manager for Cave de Gan Jurançon, Mr. Ruhlmann; Mr. Jean Bernard Larrieu, Clos Lapeyre, a large independent producer; and Pascal Labasse, an independent producer for a large domain of Jurançon wine, (since 1925), Domaine Bellegarde.

\section{Results and Implications}

Following the interviews, there appeared to be a consensus that exporting Jurançon wine to China (and other countries too) is something that most of them are now considering. The Cave de Gan de Jurançon appeared to have a strong export strategy already in place, with some wine export to the USA and South America already (since 2012) (Ruhlmann, 2014). The main obstacle appeared to be that previously most wine producers had been able to sell all of their wine, so there was no need to 'look for more customers in France and/or abroad' (Gaillot, 2014). Up until 2013, their attitude had been to let things 'tick over nicely' as they had no extra land available to be able to grow more grapes. However, with the economic crisis in France taking hold, consumers drinking less wine and the new demand from China beginning to appear, their attitude towards export is beginning to change.

The use of wine tourism and deeper involvement with big name supermarket chains has been utilized by RDVJ to increase distribution and promote the brand image. More recently, since early 2013, the independent wineries of Jurançon, (who are part of RDVJ), became interested in exporting to China, following a Chinese delegation visit to Jurançon in 2013 (Normand, 2013). This sparked interest amongst the independent wineries in the Route des Vins of Jurançon and the Export Director, Mr. Gaillot, has since initiated links with the 'Maisons du Sud Ouest' (an organisation set up to promote wine and food products from South West France nationally and internationally) and the Chamber of Commerce of Pau to undertake initial export to China. This is due to a 'strong awareness of the quality of French wines' in China which has fuelled the demand amongst the middle/upper class Chinese consumers. The key regions in China which are being targeted so far are: Chengdu and Guangzhou (Gaillot, 2014).

In his interview, Mr. Gaillot explained that Jurançon wine will use the same niche marketing strategy as in France, but the target may be slightly different. Even though the Chinese are traditionally red wine drinkers, recognising the main AOC brands in France - Bordeaux, Bourgogne, they are open and keen to try other AOC French wines. In a recent visit to China, Mr. Gaillot offered a wine tasting of selected Jurançon wines which proved particularly 
popular with female consumers, who seemed very keen on its sweet taste.

Their pricing strategy will follow the niche strategy of France, but with a considerably higher price, due to the many intermediaries and the intention of marketing Jurançon as an 'upmarket' wine. There is a large potential amongst the mid to upper classes of Chinese consumers who have a high spending power.

\section{Conclusion and Recommendations}

Although consolidation of its local and national market is a good first step, Jurançon wine producers are keen to begin to take the first steps in the process of internationalisation.

This requires working with producers of regional and other AOC food and drink products, including wine, to develop a multi-dimensional strategy that can collectively help the region to build a stronger image.

While the utility of a stronger brand image to promote internationalisation has been recognised by Jurançon wine producers and promoters, it is currently hampered by lack of market development funding. The availability of funding from the EU may help remove this constraint.

Jurançon wine producers must find simple yet innovative means to communicate its qualities relative to other offerings on the market. This approach needs to augment its perceived value to justify its price premium to both the educated and newer market segments in China and other export markets.

Consumers in target markets would be more comfortable trying a Jurançon wine if its purported qualities are placed into a familiar context. Given that this confusion afflicts the French wine industry in general, EU assistance may be available to assist Jurançon wine producers to work on these issues.

There are certain limitations to this research. As it is based on a small, French niche wine, which is in its initial stages of internationalisation, there may be many other factors that need to be considered before fully understanding the strategies that are necessary to contribute to future success.

\section{References}

Alonso, A. D., \& Northcote, J. (2009). Wine, History, Landscape: Origin Branding in Western Australia. British Food Journal, 111(11), 1248-1259, Emerald Publishing Ltd. http://dx.doi.org/10.1108/00070700911001068

Atout France. (2010). Tourisme et Vin, les Clientèles Françaises et Internationales, les Concurrents de la France. Comment ResterCompétitifs?, 95p. Marketing Touristique.

Balestrini, P., \& Gamble, P. (2006). Country-of-origin effects on Chinese wine consumers. British Food Journal, 108(5), 396-412. http://dx.doi.org/10.1108/00070700610661367

Blot, C. and Janvier, P. (2012) 'Etude Quinquennale 2010 sur la Consommation de Vin en France, France Agrimer, 27 novembre 2012.(France Agrimer: French Ministry (Department) 
of Agriculture, Food Industries and Forestry).

Bova, F. (2012). La Consommation du Vin en France en 2010, Novembre 2012, France Agrimer Synthèses. Published by the French Ministry (Department) of Agriculture, Food Industries and Forestry.

Campbell,G., \& Guibert, N. (2006). Old World Strategies Against New World Competition in a Globalising Wine Industry. British Food Journal, 108(4), 233-242. http://dx.doi.org/10.1108/00070700610657092

Cave de Gan Jurançon (Cooperative), Gan, 64000, France, http://www.cavedejurancon.com/boutique.php (accessed October 28, 2014).

Coelho, A., \& Rastoin, J. L. (2006) 'Les Stratégies de Développement des Grandes Firmes de IIndustrie Mondiale du Vin sur la Longue Période (1980-2005). Strategic Business Models Of Multinational Wine Firms: An Overview Across The Years 1980-2005, Unite Mixte de Recherche, MOISA, Marchés Organisations Institutions Stratégies dActeurs.

Council Regulation (EC) No 491/2009 of 25 May 2009. 'Amending Regulation (EC) No. 1234/2007: Establishing a Common Organisation of Agricultural Markets and on Specific Provisions for Certain Agricultural Products (Single CMO Regulation). European Union, (2009).

De Battista, T. (2011). Wine Tourism, Destination Malta, EAITM Conference : Forum For Business Education, Research and Development, University of Malta.

De La Chesnais, E. (2013). Les Exportations de Vins Français au Plus Haut en 2012, Le Figaro Newspaper, 18thFebruary 2013.2 Website: http://www.lefigaro.fr/conjoncture/2013/02/15/20002-20130215ARTFIG00547-les-exportatio ns-de-vins-francais-au-plus-haut-en-2012.php?cmtpage $=0$ (accessed 10th April 2013).

Dever, J., \& Baldi, S. (2012). EU-27 Wine Annual Report and Statistics, GAIN Report, No. IT203, 3rd January 2012.

Duquesnois,F., Gurãu,C., \& Le Roy F. (2010). Wineproducers' strategic response to a crisis situation. International Journal of Wine Business Research, 22(3), 251-268

European Commission. (2009). Commission Regulation (EC) No. 114/2009 of 6 February 2009, Official Journal L 38 of 7.02.2009.

Flick, U. (2014). An Introduction to Qualitative Research, SAGE Publications.

France Agrimer. (2012). Ventes de Vins Tranquilles en Grande Distribution - Bilan 2011 (Sales of Still Wine in Supermarkets - Annual Report 2011), April 2012, No. 4. (France Agrimer: French Ministry (Department) of Agriculture, Food Industries and Forestry).

INAO (Institut National de 1Origine et de la Qualité). (2012). (French National Institute for Origin and Quality). Official website:http://www.inao.gouv.fr/(accessed 12th December 2012) 
INSEE, Institut National de la Statistique et des Etudes Economiques. (2010). (French National Institutefor Statistics and EconomicResearch).

Julien, A. (2013). Les Exportations de Vins et Spiritueux Français Battent un Nouveau Record, Le Monde Newspaper, 14th February 2013. Website: http://www.lemonde.fr/argent/article/2013/02/14/les-exportations-de-vins-et-spiritueux-franc ais-battent-un-nouveau-record_1832800_1657007.html (accessed 10th April, 2013).

Laprun, C. (2014). Director of the Route des Vins du Jurançon. Interview in November.

Larrieu, J.B., (2014). Conférence sur le Vin and interview - ESC Pau, France, November 13 th 2014.

Marketline. (2014). France - Wine Industry Profile, Pau Business School database, France.

Moen, O., \& Servais, P. (2002). Born Global or Gradual Global? Examining the Export Behavior of Small and Medium-SizedEnterprises. Journal of International Marketing, 10(3). http://dx.doi.org/10.1509/jimk.10.3.49.19540

Normand, E. (2013). Ces vins de Jurançon qui veulent séduire les Chinois, La République Newspaper, April 29th 2013.

OIV. (2014). Statistical Report on World Vitiviniculture, International Organisation of Vine and Wine, Intergovernmental Organisation, Paris, France. Website: http://www.oiv.int (accessedJanuary 15th 2013)

Pau Portes des Pyrénées (PPP), 'Tourisme- Guide Patrimoine et Loisirs. (2013).

Pouch, T. (2011). Commerce Mondial des Vins: la France Serait-elle Distancée?, Chambre dAgriculture de France (French Chamber of Agriculture), no. 1003, Mai 2011.

Remaud, H., Beaujanot, A., \& Couderc, J.P. (2004). Wine Business Practices: A New Vs Old Wine World Perspective, Academy of Wine Business.Website: http://academyofwinebusiness.com/wpcontent/uploads/2010/05/NewVsOldWineWorldPerspe ctive.pdf

Ruhlmann, F. (2014). Interview with Export Manager of the Cave de Jurançon, November.

Saubot, P. (2014). Interview with a large Chateau owner: Domaine de Cinqua, in Artigelouve, Jurançon. November.

Strauss, A. \& Corbin, J. (1998). Basics of Qualitative Research: Techniques and Procedures for Developing Grounded Theory. SAGE Publications.

Vinetsociété.fr. (2014). An official website dedicated to all sectors of the French Wine Industry: http://www.vinetsociete.fr/chiffres (accessed April 2nd 2014)

Viot, C., \& Passebois-Ducros, J. (2010). Wine Brands or Branded Wines? The Specificity of the French Market in Terms of the Brand. International Journal of Wine Business Research, 4, 406-422. http://dx.doi.org/10.1108/17511061011092438 


\section{Macrothink}

Journal of Management Research

ISSN 1941-899X

2015, Vol. 7, No. 2

Wisker, G. (2007). The Postgraduate Research Handbook, Palgrave McMillan, 2nd Edition.

XERFI 700. (2014). La Production de Vin, janvier 2014, Pau Business School database, France.

\section{Copyright Disclaimer}

Copyright for this article is retained by the author(s), with first publication rights granted to the journal.

This is an open-access article distributed under the terms and conditions of the Creative Commons Attribution license (http://creativecommons.org/licenses/by/3.0/). 